\title{
Free cashflow and firm performance: Evidence from sectoral levels for Vietnamese listed firms
}

\author{
Le Long Hau
}

\author{
School of Economics, Cantho University, Cantho City, Vietnam
}

\begin{abstract}
Using data of listed firms on Hochiminh Stock Exchange, the study examines the impact of free cashflowson firm performance of manufacture, trade and real estates sectors. The findingsconsistently show that free cashflowshave a positive effect on firm performance for all sectors. However, the impact of free cashflows on firm performanceis different between firms with and without investment opportunities. This shows the relevance of Jensen's free-cashflows theory (1986) to listed Vietnamese firms at thesectoral level.
\end{abstract}

Keywords- Free cashflows, free-cashflows theory, firm performance.

\section{INTRODUCTION}

The concepts of free cash flow (FCF) or idle cash flow are initiated by Michael Jensen (1986). According to Jensen (1986), having large free cash flow creates conflicts within the firm, i.e. between the interests of managers and shareholders, thereby negatively affecting its performance. Many empirical studies have been done in countries around the world. Lang et al. (1989, 1991) test the theory of free cash flow, using the Tobin's $Q$ (Tobin, 1969) as a measure of the available investment opportunities of firms. The results indicate that, for companies with low Tobin's $Q$ (i.e. no good investment opportunities), profits have a negative relationship with the free cash flow present in the firm and vice versa. Other empirical studies (Brush et al., 2000; Freund et al., 2003) also find that corporate profits are negatively correlated with business free cash flow, especially for firms without good investment opportunities $(\mathrm{Q}<1)$. In addition, Chung et al. (2005), Bukit and Iskandar (2009) and Mojtahedzadeh and Nahavandi (2011) all conclude that for firms with high level of free cash flow but low growth opportunities (measured by the market value/book value ratio-P/B ratio), the presence of issues related to the agency costs may cause a negative impact on their performance.

In Vietnam, empirical research on the relationship between free cash flow and firm performance is still limited. Up to our knowledge, only research by Vinh and Chi (2013) for listed firms on the Ho Chi Minh City Stock Exchange for the period (2007-2011). However, this research has only analyzed the relationship between free cash flow of firm and its performance, without taking account of its investment opportunities as stated by the free cash flow theory. This study thereforeconductsa test on the relevance of free cash flow theory for Vietnamese listed firms at the sectoral levels. More specifically, we investigate the join effect between free cash flow and investment opportunities on firm performance for the period (2009-2015). This study will contribute to the literature for future research. Moreover, the empirical evidence of free cash flow theory is not only important to investors, but also to firm executives in order to establish more effective management policies.

\section{METHODOLOGY}

\subsection{Data}

Data is obtained from the audited financial statements of listed companies on the Ho Chi Minh City Stock Exchange, and the market price of stocks is derived from websites of VNdirect Securities Company (vndirect.com.vn). The sample consists of 90 nonfinancial corporations for the period 2009 - 2015. Financialsare not included in the sample due to their particular characteristics, i.e they are subject to strict regulations and have a different accounting mechanism.Firmsare divided into 3 main sectors comprising of manufacture, trade and real estate, according to the criteria by the stock market data provider (Vietstock.vn).

\subsection{Empirical specification:}

Based on previous empirical studies, we propose the empirical model as follows:

$R O A_{i t}=\alpha_{0}+\alpha_{1} F C F_{i t-1}+\alpha_{2} Q_{d u m_{i t-1}}+\alpha_{3} Q_{\text {dum }}$ dit-l $* F C F_{i t-1}+$ $\alpha_{4} S A L E_{i t}+\alpha_{5} S I Z E_{i t}+\alpha_{6} A S S T_{i t}+\alpha_{7} O P E R_{i t}+\alpha_{8} D A+\mu_{i}$

in which:ROA it is the return-on-asset ratio of firm $\mathrm{i}$ at the end of year t; $Q D U M_{i t-1}$ is a dummy for the investment opportunities of firm $\mathrm{i}$ at the end of year ( $\mathrm{t}-1)(Q D U M=1$ if Tobin's $\mathrm{Q}<1$ : no investment opportunities; $Q D U M=0$ if Tobin's $Q>=1$ : with investment opportunities); $F C F_{i t-1}$ : Free firm cashflowsi at the end of year (t-1); Qdum ${ }_{i t-}$ ${ }_{1}{ }^{*} F C F_{i t-1}$ is an interaction variable between the investment opportunities and free firm cashflows at the end of year (t-1); $S A L E_{i t}$ describes the sales growth of firm i at year $\mathrm{t}$; $S I Z E_{i t}$ : size of firm i at year end of year $\mathrm{t} ; A S S T_{i t}$ is as sets 
turnovers of firm $\mathrm{i}$ at the end of year $\mathrm{t}$; OPER $i$ indicates the operating costs on sales of firm $i$ at the end of year t; $D A_{i t}$ represents the debt-on-asset ratio of firm $i$ at the end of year $\mathrm{t}$ and $\mu_{\mathrm{i}}$ is the error terms.

Calculation of variables:

$R O A$ - Returns on assets: In most of previous studies (e.g., Vinh and Chi, 2013; Yungchih, 2010; Liao, 2008),ROA is computed based on net profit after tax and total assets from the financial statements, Yet, this calculation is limited, i.e the total assets include nonoperating assets and net profit depends on firm's financial leverage. As financial leverage increases, net income decreasesdue to an increase in interest costs. This leads to a decrease in ROA although the business performance remains unchanged. In order to overcome the limitations in calculating ROA of previous studies, some adjustments in after-tax net profit and total assets are made as follows:
-Net profit after tax: For returns to be independent of the firm's financial leverage, interest payments is not included in costs to determinethe operating profits. Hence, interests (after tax) must be added back to aftertax net profit if the total assets are financed by debts.

-Total assets: Non-operating assets (excess cash and short-term financial investments)are excluded from the firm's total assets for computing ROA. With high liquidity and low risk, these assets mayproduce very small profits and incur great opportunity costs. Therefore,without excluding those from the total assets may distort the value of ROA. However, since the financial statements do not provide data on the amount of excess cash, this study excludes the item "Cash and cash equivalents" reported on the balance sheet from the total assets.

$$
R O A=\frac{A f t e r \text { tax net returns }+ \text { Interest }(1-\text { Tax rate })}{\text { Average total assets }-(\text { Cash and cash equivalents }+ \text { Short term financial investment })}
$$

FCF (Free cashflows): The free cashflow of a firm is the amount of money generated by the firm after it has covered all necessary operating expenses (including investments in fixed assets and working capital). The free cashflow is determined by the following formula (Vinhvà Chi, 2013):

$$
F C F=\frac{\text { EBIT } x(1-\text { Tax rate })+\text { Depreciation }- \text { Working capital changes }- \text { Capital stocks }}{\text { Gross sales }}
$$

Tobins' $Q($ Tobin, 1969)of a firm indicates whether it has the opportunity to invest. Tobin's $Q$ reads

$$
\text { Tobin's } Q=\frac{(M V P S \times N O S)+D E B T}{T A B}
$$

in which:MVPSis market value per share at the end of year; NOS presentsnumber of outstanding stocks at the end of year; $D E B T$ is book value of total debts; $T A B$ shows book value of total assets.

Control variables are defined as follows:

SALE - Sales growth (\%): defined as gross sales at year $\mathrm{t}$ divided by gross sales in the previous year ( $\mathrm{t}-1)$ (Brush et al.,2000); Liao, 2008; Vinhvà Chi, 2013).

SIZE - Firm size (\%): defined as logarit of total firm assets (Martaniet al., 2009; Yungchih, 2010; Heydariet al., 2014).

ASST-Assets turnovers(\%): defined as gross sales divided by average operating assets (Martaniet al., 2009; Yungch ih, 2010).

OPER - Operating-costs-to-sales ratio (\%): defined as the total selling and administrative costs divided by gross sales (Vinhand Chi, 2013; Yungchih, 2010).
$D A$ - Debt-on-asset ratio (\%): defined as the average debt divided by average operating assets (Martaniet al., 2009; Brush et al., 2000; Vinhand Chi, 2013).

\subsection{Estimation method}

Panel regression is estimated using two models: fixedeffects model (FEM) and random-effects model (REM). The Hausman test is used to select between FEM and REM model. In addition, the tests to check for reliability of the regression model are also performed such as multicollinearity (VIF), heteroschedasticity (Wald test) andautocorrelation (Plasman, 2006).

\section{EMPIRICAL RESULTS}

3.1 Summary statistics and correlation matrix of variables

Descriptive statistics for variables are shown in Table 1. In general, no outliers in data can be observed, showing the reliability of the estimated results. 
Table.1: Summary statistics

\begin{tabular}{|l|c|r|r|r|r|}
\hline \multicolumn{1}{|c|}{ Variables } & \multirow{2}{*}{ Observations } & \multicolumn{1}{c|}{ Mean } & \multicolumn{1}{c|}{ Std. } & \multicolumn{1}{c|}{ Min } & \multicolumn{1}{l|}{ Max } \\
\hline ROA & 540 & 0.1102 & 0.1177 & -0.2844 & 1.2628 \\
\hline FCF & 540 & -0.0396 & 0.5084 & -5.8058 & 4.1817 \\
\hline SALE & 540 & 1.1596 & 0.4810 & 0.0893 & 4.4424 \\
\hline OPER & 540 & 0.1196 & 0.1008 & 0.0013 & 0.7772 \\
\hline DA & 540 & 0.5492 & 0.2143 & 0.0204 & 1.0473 \\
\hline SIZE & 540 & 20.6545 & 1.2118 & 18.2951 & 25.5707 \\
\hline ASST & 540 & 1.4268 & 1.5089 & 0.0237 & 12.5143 \\
\hline
\end{tabular}

From the matrix of correlation among the variables in Table 2, we find that the correlation between variables is relatively small (less than 0.8). Therefore, the possible effects of multi-collinearity in regressions are negligible (Nam, 2008).

Table.2: Correlation matrix between variables

\begin{tabular}{|lrrrrrrrr|}
\hline & FCF $_{\mathbf{t}-\mathbf{1}}$ & QDUM $_{\mathbf{t}-\mathbf{1}}$ & QF $_{\mathbf{t}-\mathbf{1}}$ & SALE & OPER & DA & SIZE & ASST \\
\hline FCF $_{\mathbf{t}-\mathbf{1}}$ & $\mathbf{1 . 0 0 0 0}$ & & & & & & & \\
QDUM $_{\mathbf{t}-\mathbf{1}}$ & -0.0006 & $\mathbf{1 . 0 0 0 0}$ & & & & & & \\
QF $_{\mathbf{t}-\mathbf{1}}$ & 0.6483 & -0.0643 & $\mathbf{1 . 0 0 0 0}$ & & & & & \\
SALE & -0.0234 & -0.0832 & 0.0841 & $\mathbf{1 . 0 0 0 0}$ & & & & \\
OPER & -0.2978 & -0.0876 & -0.1182 & -0.0993 & $\mathbf{1 . 0 0 0 0}$ & & & \\
DA & -0.0848 & -0.0033 & 0.0351 & 0.0673 & -0.1323 & $\mathbf{1 . 0 0 0 0}$ & & \\
SIZE & -0.2123 & -0.0818 & -0.1259 & 0.1031 & 0.0942 & 0.3448 & $\mathbf{1 . 0 0 0 0}$ & \\
ASST & 0.1097 & -0.2071 & 0.0571 & 0.0035 & -0.2588 & 0.0464 & -0.2484 & $\mathbf{1 . 0 0 0 0}$ \\
\hline
\end{tabular}

\subsection{Findings}

Results of the regression models for 3 sectors (manufacturing, trading or real estate) are presented in Table 3. Hausman test shows that the fixed-effects estimation (FEM) method is more appropriate than the random effects (REM) for all sectors;hence the results from FEM will be presented. In addition, appropriate tests show the presence of heteroskedasticity and autocorrelation. Therefore, the model is estimated with robust standard errors. The variance inflation factor (VIF) values of all variables are less than 10, therefore the effect of multi-collinearity is negligible.

The estimated coefficients of free cash flow (FCF) are found to be significantly positive at $1 \%$ to $10 \%$ level across all three sectors. Notably, the coefficient for manufacture sector is relatively greater than that for the other sectors $(0.251$ versus 0.048 and 0.012 for trade and real estate, respectively). This shows that the free cash flow has a positive impact on firm performance is positive for all sectors, in which the effect is fairly stronger for manufacture sector. These results are in line with previous studies (E.g., Liao, 2008; Brush et al., 2000; Yungchih, 2010), and could be explained by the fact that compared to trade and real estate sectors; the manufacture sector uses a much smaller financial leverage degree. Their investments are financed mainly by firm's free cashflows.
Thecoefficient of dummy variable for firm investment opportunities (QDUM) is negative for all sectors $(-0.027$, -0.040 and -0.018 for manufacture, trade and real estate sectors respectively), where it is statistically significant at the $1 \%$ level for manufacture and trade sectors. This indicates the lower efficiency of firm with no investment opportunities than the others.Similarly, the coefficient of interaction variable between investment opportunities and free cashflows QF (=QDUM*FCF) are only statistically negatively significant for firms in manufacturing and trade sectors $(-0.210$ and $-0,051$, respectively), while that is not the case for real estate sector (though also having a negative coefficient). The total effect of free cashflows is defined by summing both coefficients ofthe free cash flow (FCF) and interaction variable $(\mathrm{QF})$. As can be seen, the total value of the two coefficients is about $0.041,-0.003$ and 0.005 for manufacture, trade and real estate sectors respectively.Obviously, taking into account firm investment opportunities, the impact of free cashflows on firm performance is significantly reduced(almost zero).These results indicate thatwhen firms have investment opportunities, free cashflowsmay significantly increasefirm performance and vice versa. These findings support the theory of free cashflows initiated by Jensen (1986).

As for the real estate sector, both the coefficients of 
QDUM and QF are not statistically significant athoughshowing the correct signlike for the other sectors, which also supports the theory of free cashflows. This could be attributed to the following facts.According to Tobin's investment theory (1969), the investment opportunity of a firm (or Tobin's Q) depends mainly on itsstock and debt market values. However, during the study period the stock prices of real estate firmshighly depend on fluctuations of the stock market rather than their business outcome. As the market grows hot, stock prices rise despite the slowdown inreal estate market and vice versa. Moreover, when the real estate market is bubble, regardless of firm business outcome, all stock pricesare also falling. In other words, stock price changes do not reflect the true performance of the business. Therefore, firm performance (ROA) cannot be explained by the investment opportunities of real estate firms measured with Tobin $Q$ during the study period.

For control variables of the model: Regression results show that the estimated coefficient of firm size variable (SIZE) is negative and statistically significant with the 95\% confidence level for the manufacturing sector, indicating the negative relationship between firm size and its performance. This shows that scale-up does not always bring benefits for firms. As the scale increases, the administration of firm becomes more complicated. If these problems are overcomed, firms can achieve better performance due to economies of scale. Yet, if that is not the case, firms may be in a situation of high production costs, stagnant goods or inefficient use of funds, which in turn adversely affect their business outcome. This result is consistent with the results of Kumar (2004), and Vinh and Chi (2013). Similarly, the coefficient of sales growth (SALE) is statistically positively significant at the 5\% level for manufacturing only, indicating that sales growth has the positive effect on firm performance for manufacturing sector. This is consistent with the theory and previous studies (Martani et al., 2009; Yungchih, 2010). For the other sectors, those variables are not statistically significant. The remaining control variables, including OPER, DA and ASST, are not statistically significant for all three sectors. These results are similar to Vinh and Chi (2013).

Table.3: Regression results for all sectors

\begin{tabular}{|c|c|c|c|c|c|c|}
\hline \multirow{3}{*}{ Variables } & \multicolumn{6}{|c|}{ Sectors } \\
\hline & \multicolumn{2}{|c|}{ Manufacture } & \multicolumn{2}{|l|}{ Trade } & \multicolumn{2}{|c|}{ Real estates } \\
\hline & Coefficients & $t$-value & Coefficients & $t$-value & Coefficients & $t$-value \\
\hline $\bar{C}$ & 1.251 & 2.39 & 0.214 & 0.66 & -0.019 & -0.02 \\
\hline$F C F_{(t-1)}$ & $0.251 * * *$ & 3.45 & $0.048^{*}$ & 2.03 & $0.012 * *$ & 2.29 \\
\hline$Q D U M_{(t-1)}$ & $-0.027 * *$ & -2.41 & $-0.040 * * *$ & -5.28 & -0.018 & -1.29 \\
\hline$Q F_{(t-1)}$ & $-0.210 * *$ & -2.28 & $-0.051 *$ & -1.85 & -0.007 & -0.69 \\
\hline$S A L E$ & $0,081 * *$ & 2,46 & 0.009 & 0.45 & -0.011 & -1.57 \\
\hline OPER & 0,337 & 0,95 & -0.251 & -0.68 & -0.027 & -0.42 \\
\hline$D A$ & 0,007 & 0,12 & -0.120 & -0.93 & 0.160 & 1.62 \\
\hline SIZE & $-0,064 * *$ & $-2,58$ & -0.002 & -0.13 & -0.002 & -0.06 \\
\hline$A S S T$ & 0,035 & 1,40 & $0.012 *$ & 1.85 & $0.159 * *$ & 2.63 \\
\hline No. of observations & 342 & & 72 & & 126 & \\
\hline$F$-statistic & 8.62 & & 36.21 & & 6.26 & \\
\hline $\operatorname{Prob}(F)$ & 0.000 & & 0.000 & & 0.000 & \\
\hline $\mathrm{R}^{2}$ & $28.08 \%$ & & $40.53 \%$ & & $43.85 \%$ & \\
\hline
\end{tabular}

Notes: $*, * *$ and $* * *$ denote the significance levels of $10 \%, 5 \%$ and $1 \%$, respectively.

\section{CONCLUSIONS AND POLICY RECOMMENDATIONS}

Several findings from the study can be summarized for the three sectors under investigation comprising of manufacture, trade and real estates. Firstly, in general free cash flow has a positive impact on firm business performance. In addition, firms with investment opportunitiesshow ahigher business performance than those without investment opportunities. Finally, the impact of free cash flow on business performance is heterogeneous, in which free cash flow has the effect of enhancing the performance of firms with investment opportunities, but that is not the case for firms without the opportunity to invest. These results have shown the relevance of Jensen's free cash flow theory (1986): when firms generate large free cash flows (FCF) but do not have profitable investment opportunities, managers of these companies tend to abuse cash flow in their hands to 
invest in low-yield, even negative profit projects, rather than paying back to their shareholders.Remarkably, among the three investigated sectors, the evidence is strongest for the manufacturing sector and is weakest for the real estates sector.This could be explained by the bubbles of stock prices of real estates firms in the research time period.

From the above analysis, it can be clearly seen that free cash flow control is always one of the most important issues of firms. If a firm does not have good investment opportunities available, holding more cash may not increase the firm performance. In constrast,for firms without investment, free cash flow may create opportunity costs, or firm managers may abuse this free cash flow for personal gain. These problems can reduce the overall performance of the business. Therefore, building a reasonable cash flow control strategy will bring efficiency to the firm, thereby enhancing the firm value.

\section{REFERENCES}

[1] Brush, Thomas H., Philip Bromiley and MargarethaHendrickx, 2000.The Free Cash Flow Hypothesis for Sales Growth and Firm Performance.Strategic Management Journal, 21: 455-472

[2] Bukit, Rina $\mathrm{Br}$ and TakiahMohdIskandar, 2009.Surplus Free Cash Flow, Earnings Management and Audit Committee.Int. Journal of Economics and Management, 3(1): 204 - 223.

[3] Chung, Richard, Michael Firth and Jeong-Bon Kim, 2005.Earnings Management, Surplus Free Cash Flow, and External Monitoring.Journal of Business Research, 58: 766-776.

[4] Freund, Steven, Alexandros P. Prezas and Gopala K Vasudevan, 2003.Operating Performance and Free Cash Flow of Asset Buyers. Financial Management, 32: 87-106.

[5] Gelman, Andrew and Iain Pardoe,2006.Bayesian Measures of Explained Variance and Pooling in Multilevel (Hierarchical) Models.Technometrics, 48 241-251.

[6] Hausman, J., 1978. Specification Tests in Econometrics.Econometrica, 46: 1251-1271.

[7] Hong, Zhou, Yang Shutingand ZhangMeng, 2012.Relationship between Free cash flow and Financial Performance Evidence from the Listed Real Estate Companies in China.International Proceedings of Computer Science \& Information Tech, 36: 331-335.

[8] House, William C. \&Michael E. Benefield,2005.The Impact of Sales and Income Growth on Profitability and Market Value Measures in Actual and Simulated Industries.Developments In Business Simulation \& Experiential Exercises, 22: 56-62.

[9] Jensen, Michael C., 1986. Agency Costs of Free Cash Flow, Corporate Finance, and
Takeovers.American Economic Review, 76: 323329.

[10] Jensen, Michael C., 1993. The modern industrial revolution, exit, and the failuer of control system.Journal of Finance, XLVIII (3): 831880.

[11]Lang, Larry H. P., Rene M. Stulz and Ralph A. Walkling, 1989.Mangerial performance, tobin's Q and the gain from successful tender offers. Journal of Financial Economics, 24: 137-154.

[12] Lang, Larry H. P., Rene M. Stulz and Ralph A. Walkling,1991.A Test of the Free Cash Flow Hypothesis - The case of Bidder Returns.Journal of Financial Economics, 29: 315 - 335.

[13]Liao, Y.-M., 2008.Do Free Cash Flow and Sale Growth Affect Firm Performance in Taiwan?Thesis of Degree Master.Chaoyang University of Technology.

[14] Martani,Dwi, Mulyono and RahfianiKhairurizka, 2009. The Effect of Financial Ratios, Firm Size, and Cash Flow from Operating Activities in The Interim Report to the Stock Return. Chinese Business Review, 8: 44-55.

[15] Mojtahedzadeh, Vida, andNasimNour Ali Pour Nahavandi, 2011. FCF Agency Costs, Earnings Management, and Investor Monitoring.Social Science Research Network.

[16] Murphy, Kevin J., 1985. Corporate Performance and Managerial Remuneration, An Empirical Analysis. Journal of Accounting and Economics, 7: 11-42.

[17] Plasman, J. 2006. Modern linear and nonlinear econometrics, Springer Verlag.

[18] Richardson, Scott, 2006. Over-investment of free cash flow.Rev Acc Stud, 11: 159-189.

[19] Talebian, G. A., Valipour H., and Askariz, 2012. Effect of Free cash flow Agency problem on the Value Relevance of Earning per Share and Book value per Share with Stock price in the Chemical and Medical industries: Evidence from Tehran Stock exchange (TSE). American Journal of Scientific, 46: 118-127.

[20] Tobin, J. 1969. A general equilibrium approach to monetary theory. Journal of Money, Credit and Banking, 1, 15-29.

[21] VoXuanVinh and Doan Thi Le Chi, 2013. Free cash flows and firm performance of Vietnamese firms.Journal of Economics Development, 280: 6177.

[22] Yungchih, W. G., 2010.The Impacts of Free Cash Flows and Agency Costs on Firm Performance. Journal Service Science \& Management, 3:408-418. 